A GLOSSARY OF SOCIOLINGUISTICS 



\title{
A Glossary of Sociolinguistics
}

\author{
Peter Trudgill
}

Edinburgh University Press 
(C) Peter Trudgill, 2003

Edinburgh University Press Ltd 22 George Square, Edinburgh

Typeset in Sabon

by Hewer Text Ltd, Edinburgh, and printed and bound in Great Britain by

CPI Antony Rowe, Eastbourne

Transferred to digital print, 2007

A CIP record for this book is available from the British Library

ISBN 0748616233 (paperback)

The right of Peter Trudgill to be identified as author of this work has been asserted in accordance with the Copyright, Designs and Patents Act 1988. 